\title{
Correction to: Anaerobic digestion of citrus industry effluents using an Anaerobic Hybrid Reactor
}

\author{
E. S. Rosas-Mendoza ${ }^{1}$ ·. M. Méndez-Contreras ${ }^{1} \cdot$ A. Martínez-Sibaja ${ }^{1}$ N. A. Vallejo-Cantú ${ }^{1}$ - A. Alvarado-Lassman ${ }^{1}$
}

Published online: 22 January 2018

○) Springer-Verlag GmbH Germany, part of Springer Nature 2018

Correction to: Clean Technologies and Environmental Policy https://doi.org/10.1007/s10098-017-1483-1

In the original publication of the article, the corresponding author name was published incorrectly as A. Lassman-Alvarado. This has been updated in this correction article. The original article has also been corrected.

The original article can be found online at https://doi.org/10.1007/ s10098-017-1483-1.

\footnotetext{
A. Alvarado-Lassman

lassman@prodigy.net.mx

1 División de Estudios de Posgrado e Investigación, Instituto Tecnológico de Orizaba, Av. Oriente 9, 852. Col. Emiliano Zapata, C.P. 94320 Orizaba, Mexico
} 